\title{
Road development and Indigenous hunting in Tanah Papua: Connecting the facts for future wildlife conservation agendas
}

\author{
Freddy Pattiselanno 1,2,3*, Andrew Krockenberger ${ }^{3}$ \\ 1 Faculty of Animal Science, Universitas Papua, Manokwari \\ 2 Biodiversity Research Centre, Universitas Papua, Kampus UNIPA, Jl. Gunung Salju Amban Manokwari \\ 98314 - Papua Barat \\ 3 College of Science and Engineering, James Cook University, Cairns, Queensland, Australia. \\ * Correspondence author: f.pattiselanno@unipa.ac.id; Tel.: +62 82237946333
}

\begin{abstract}
Road development is increasing worldwide. Generally, examples of road building in tropical countries demonstrate that road access can assist the fight against rural poverty, but such developments are also linked to deforestation, pollution, invasions of exotic species, and environmental degradation. For Papua and West Papua provinces (Tanah Papua) in Indonesia, the development of the provincial road network is intended to improve the rural economy, aiming to alleviate poverty within isolated rural areas. However, road development can pose particularly challenging problems to rural and Indigenous communities. Poorly planned roads can be devastating when they provide easy access to illegal hunting that threatens endangered species. In this study, we discuss how road development in Tanah Papua has changed indigenous hunting. Native Papuans have benefited from improved road access, which allows them to sell their agricultural products at local markets. Increased road connectivity has also changed how local people use natural resources and forest products, moving from subsistence to a more market-based orientation. Although policies on infrastructure development including roads form part of Indonesia's national program, they are not automatically compatible with a sustainable development program in Tanah Papua. To foster more equitable and sustainable road development, government agencies must improve their overall coordination of further road expansion plans by promoting green infrastructure that supports the sustainable use of natural resources in a way that is reconciled with traditional knowledge of local people. Such efforts may also have positive effects on the efforts to protect biodiversity within the wider government conservation agendas.
\end{abstract}

Keywords: Road, poverty alleviation, Indigenous hunting, wildlife conservation, Tanah Papua

\section{Introduction}

Roads play important roles where there are strong economic incentives to provide access to large-scale logging, oil and mineral operations as well as agribusiness (Laurance \& Balmford, 2013). An efficient transport system contributes to economic growth thanks to the following main factors: reduced production costs, economies of scale, employment opportunities, connectivity, market integration and accessibility (Chohan et al., 2011). The International Energy Agency predicts that by 2050 there will be $60 \%$ more roads than in 2010 . That equates to about 25 million kilometres of new paved roads, enough to circle the Earth more than 600 times (Laurance, 2014). On the other hand, there is a growing awareness that road development can have major environmental and social impacts. This includes damage to sensitive ecosystems, loss of productive agricultural lands, resettlement of large numbers of people, permanent disruption of local economic activities, demographic change, accelerated urbanisation, and introduction of diseases (Trombulak \& Frissel, 2000; Laurance et al., 2009, 2015).

Human development currently brings with it an increase in the number of roads to fulfill transport needs, but this increase can have costly implications for nature (Forman et al., 2003; Pratt 
and Lottermoser, 2007). In Indonesia, the development of the Papua and West Papua provincial road network creates new settlement areas along the road and more entry points closer to forests. About $25 \%$ of protected areas in Papua are located less than $20 \mathrm{~km}$ from the $2,700 \mathrm{~km}$ of new road developed and their connections (Anggraeni \& Watopa, 2004). The newly established road networks provide more access to hunters to hunting locations, connects resources directly to available markets and consequently increases harvest rates (Robinson et al., 1999, Lee, 2000; Clayton and Milner-Gulland, 2000).

Traditionally, hunting was an extremely important livelihood activity in Papua because it provided the majority of animal protein for families (Pattiselanno, 2006). In remote areas of Papua, where access to alternative protein sources are limited and food sources from wildlife are available, hunting is conducted for household consumption (Pattiselanno, 2004, 2006). However, road development has also created livelihood options and market-based livelihoods that are now increasingly common in the Bird's Head Peninsula (Pattiselanno et al., 2020). Deer meat (venison) was one of the key hunting products, as it provides a large amount of meat for both subsistence and sale (Pattiselanno and Koibur, 2018; Pattiselanno et al., 2019; 2020).

Learning from experiences in other tropical sites, we discuss the ongoing effect of changes in road development on indigenous hunting in Tanah Papua (both Papua and West Papua provinces). We argue that road expansion for Tanah Papua's economic and livelihood development will continue to be a critical factor driving the exploitation of wild meat through hunting that increases pressure on wildlife populations. In what follows, we offer a literature review and propose new approaches for future wildlife conservation agendas based on the current situation in the field.

\section{Road development in Tanah Papua}

Large-scale infrastructure development, including transportation infrastructure, is a government priority in both Papua and West Papua provinces. The rationale is to improve the rural economy in order to alleviate rural poverty in isolated rural areas. It has been estimated that in 2000 , a total of $2,700 \mathrm{~km}$ are planned, consisting of $1,500 \mathrm{~km}$ of national networks and 1,200 km of provincial network. By 2001, more than 1,250 km had already been developed, which is approximately $50 \%$ of the planned road construction (Mertens, 2002). A total of $468 \mathrm{~km}$ of road length will further be developed, to complete the $3,146 \mathrm{~km}$ of planned road development within the period 2020 and 2025 at a cost of IDR 4.49 Trillion ( US \$319.5 million) (Walhi, 2020). The construction of roads in Papua also supports three central foci of national strategic areas on the Indonesia-Papua New Guinea border (Forest Watch Indonesia, 2020). In West Papua, the acceleration of the development of the Trans-West Papua section is devoted to supporting the Special Economic Zones (KEK), Sorong KEK and Industry Areas (KI) of Teluk Bintuni (Forest Watch Indonesia - FWI, 2020). KEK are the areas with boundaries that are covered by regions to carry out economic functions and obtain certain facilities. Meanwhile $\mathrm{KI}$ are also known as trading areas, or areas designated and planned for industrial development purposes. Infrastructure and road development in Indonesia, including the Trans-Papua highway, are regulated by laws and government regulations such as RI Law No.38, 2004 about roads, including the implementation of road construction and the government's duties and responsibilities in road construction. There is also RI Law No. 22, 2009 regulating road traffic and the transport network, including movement of people and goods on the national, provincial, district, city and village roads. Government Regulation PU No. 11/PRT/M/2011 relates to the guidelines for the implementation of special roads.

In 2014, during his four-day trip to Papua and West Papua, President Joko "Jokowi" Widodo promised to complete the Trans-Papua Highway (Diela, 2015) (Figure 1). However, construction has been postponed for various reasons, including safety. Construction first began in 2013. As the construction proceeds in fits and starts, a regional 'development corridor' is emerging along the Trans-Papuan Highway crossing Papua and West Papua provinces. This corridor is one of a series of 
national development initiatives (CMEA, 2011), to improve market access and economic growth, as well as the health of households and follows the broader global trends in infrastructure development (Alamgir et al., 2017; Clements et al., 2014; Laurance and Burgues, 2017). Yet the construction of the Papua corridor has raised concerns over environmental degradation and equitable economic development (Pattiselanno and Arobaya, 2015). Once established, road networks can bring hunters closer to hunting sites, linking resources more directly to markets in a manner that increases harvest rates (Robinson et al., 1999, Lee, 2000; Clayton and Milner-Gulland, 2000).

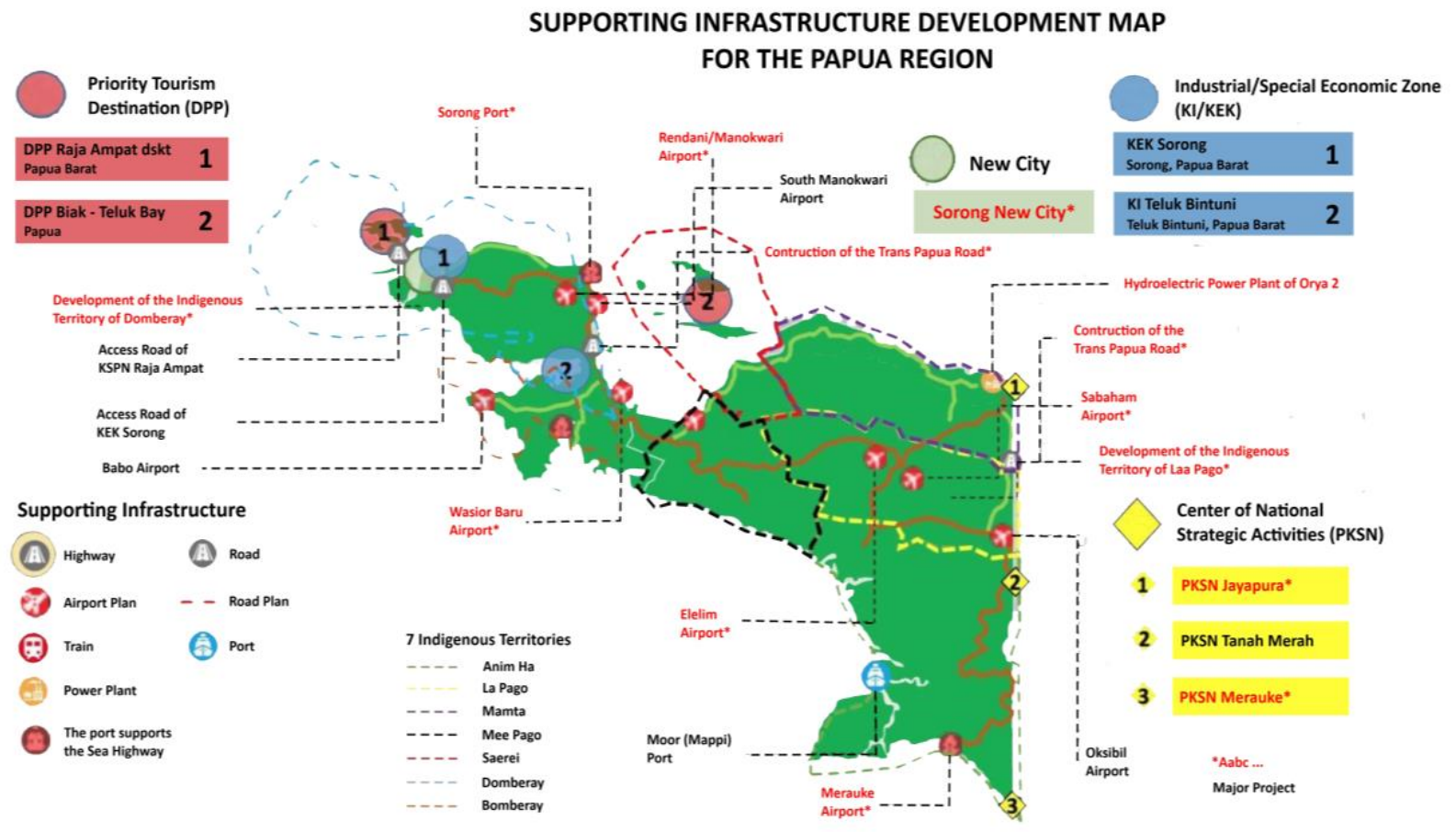

Figure 1. Supporting Infrastructure Development Map for the Papua Region (FWI - Forest Watch Indonesia)

A major consequence currently faced by infrastructure development, especially roads, is the loss of important "sacred" forests - "pamali forests" in the local dialect - and other cultural sites. However, a prominent example of how current practices have been widely acknowledged can protect the forest is "Igya ser hanjop" or "stand guard at the border," a customary law for forest protection implemented by Arfak people at the Arfak Mountain Nature Reserve (Laksono et al., 2001). The loss of these important places greatly affects the lives of native Papuans in the villages, since they consider forests to be a sacred mother. The loss of forests can disenfranchise native Papuans from their traditional landscapes and lifestyles and erode traditional knowledge and practices. These are passed down from ancestors and still guide actions of Indigenous Peoples, and may require formal and legal protection to survive. In the era of special autonomy, - the Papuan People's Assembly (MRP) - supports the empowerment of socio-cultural aspects through growing efforts in traditional knowledge values (MRP, 2009). Incorporating local knowledge practices into the local curriculum in schools is one way of teaching traditional knowledge for nature protection to youth.

Another means of protecting local knowledge and informing communities of the impacts of development is by working with the Church, which is the most respected institution in the region and plays an important role in the lives of native Papuans. Collaboration between religious leaders, traditional leaders, and village officials is very important to increasing people's awareness of the importance of biodiversity for the community and of how poorly planned roads can generate negative impacts on society and biodiversity. Therefore, efforts to work with churches and 
community groups should be enhanced to increase community awareness (Lee, 2000). Efforts to bring together a diverse array of stakeholders may also provide wider benefits and support longerterm plans for biodiversity conservation in Tanah Papua.

\section{Impacts of roads on hunting}

Why are roads particularly bad for rainforests? Laurance (2009) characterises roads as "rainforest killers" that directly eradicate species within and around them. The expansion of roads leads to increasing and accelerating forest loss. In addition to facilitating access to forests, road connections decrease the time spent to transport wildlife to markets, thereby facilitating the bushmeat trade (Mendelson et al., 2003). Available access also provides more significant opportunities for hunters to transport and sell the meat from rural to urban areas (Adefalu et al., 2012; Olupot et al., 2009; Pattiselanno et al., 2020). The extension of the 2,508-km road network in Sumatra, for example, has increased habitat loss that has led to an increase in the number of humans killed by tigers and reduced the population of the endangered Sumatran tiger and other wildlife species (Shepherd and Magnus, 2004). In Kalimantan, the development of the Malinau district at the edge of the Kayan Mentarang National Park has destroyed large areas of wildlife habitat. Roads also threaten nomadic and large vertebrates, such as the Malayan sun bear, bearded pig and the Bornean orang-utan (Meijaard et al., 2005). Improvements to highway connectivity between North Sulawesi and other provinces in Sulawesi, such as Gorontalo and Central Sulawesi, have led to the increased importation of wild meat from other parts of Sulawesi to supply wildife market demands in Manado and Minahasa (Lee, 2000), consequently elevating hunting pressure on wildlife populations (Clayton \& Milner-Gulland, 2000). The influence of markets and road availability on wildlife hunting is well-documented and includes the integration of hunting with markets, and increased harvest rates which decreases sustainability (Bennett et al., 2000; Robinson \& Bennett, 2004; Fusari \& Carpaneto, 2006; Luskin et al., 2014).

Evidence from other tropical forests suggests that increases in road connectivity are likely to transform local communities and the way they use forest resources, reducing the sustainability of hunting (Clayton \& Milner-Gulland, 2000; Lee, 2000; Milner-Gulland et al., 2003). If areas are easily accessible, outsiders can enter them to hunt, thereby increasing hunting pressure on the wildlife resources (Auzel and Wilkie, 2000; Fimbel et al., 2000; Noss, 2000), and breaking down any traditional controls that might be in place (Bennett et al., 2000; Mena et al., 2000). In Tanah Papua, the expansion of road connections in Nimboran District expanded access that led to increased harvest rates of the hunting targets (Pangau-Adam et al., 2012). Currently, in areas where roads are connecting rural areas along the coasts with towns in Tambrauw Regency, wild meat is being transported and sold using motor vehicles (Pattiselanno et al., 2020). As the distance between hunted areas to markets and other commercial centres decreases, market-driven hunting tends to increase (Bennett et al., 2000; Clayton \& Milner-Gulland, 2000).

\subsection{The link between roads and Indigenous hunting in Tanah Papua}

Motivations for hunting vary between sites (Pattiselanno et al., 2020; Pattiselanno et al., 2019; Pattiselanno \& Koibur, 2018). In sites without road access, hunting is mostly conducted to obtain meat for family consumption, whereas hunting for trade is more common in sites with road access. Several hunting techniques are employed and typically hunters use more than one technique on hunting excursions. Traps are predominantly used along roadsides, showing how hunters reorient their hunting practices towards export rather than subsistence. Normally, native Papuans use traditional hunting weapons made from forest materials. Various kinds of timbers, bamboo, lianas, palm leaves and plant fibres are used to build traps, bows and arrows and spears (Pattiselanno, 2006). The associated changes, especially in hunting, are demonstrated by a shift from subsistence hunting to market-based hunting. Pattiselanno et al. (2020), finds that wild meat from hunters was 
transported to town through the current roads, to the traders, or directly to the restaurant owners. Currently, where roads connect rural areas with towns, intermediaries use motor vehicles to transport wild meat. The fresh meat reaches consumers in restaurants in the nearest towns more quickly than before. Transforming forest landscapes into agricultural plantations and developing infrastructure such as roads has changed wildlife composition. In turn, this land use and land cover change has impacted indigenous hunting (Pattiselanno and Koibur, 2018).

In the Supiori Regency of Papua Province, newly established road networks have increased threats to the Victoria crowned pigeon (Goura victoria) due to changed hunting practices among local communities (Keiluhu, 2013). Similarly, the Trans-Papua corridor connecting Jayapura and Sarmi regency has pushed up harvest rates of Goura victoria by indigenous hunters (Keiluhu, 2013). According to Pangau-Adam et al. (2012), the presence of logging roads in Nimboran District expanded access to more sites within $5 \mathrm{~km}$ of the villages. This also led to increased harvest rates of mammals such as wild boar, rusa deer, grizzled tree-kangaroo, common spotted cuscus and Northeast common cuscus. Roads and trails provided access to the forest, and logging concessions, may also have negative effects on the Goura victoria and other wildlife populations (Keiluhu, 2013) due to increased demand for bushmeat.

Experiences in other tropical sites demonstrate that road development poses numerous challenges. A poorly planned road can be devastating to both communities and endemic species. Road expansion can also provide easier access to illegal hunting that threatens endangered species. Hunting pressures have been shown to be positively correlated with road development, as it provides greater access for hunters and traders to undisturbed forests (Robinson \& Bennett, 2000; Milner-Gulland et al., 2003). In Papua, road development also threatens endangered species such as the Grizzled tree kangaroo and Dusky pademelons (Pattiselanno and Arobaya, 2015).

Nowadays, the loss of habitats and forest fragmentation due to logging, plantation, transmigration, cultivation, mining, oil and gas extractions, and rapid development of settlements and roads threaten Papua's unique biological heritage (Richard and Suryadi 2002). Once roads are established, new entry points are created that provide more opportunities to access remote forest areas particularly for hunting wildlife (Pattiselanno and Arobaya, 2013). Currently, road development is the highest priority of the local government in Tanah Papua, but it has not fully considered its negative impacts. There are allegations that road construction will simultaneously become an economic corridor for greater natural resource-based investment. Ultimately, it all comes down to boosting the Master Plan for the Acceleration and Expansion of Indonesian Economic Development (MP3EI) as part of a grand national development strategy (Forest Watch Indonesia - FWI, 2020) rather than an effort aimed at more sustainable local development.

\section{Conclusions}

The implementation of relevant laws and decrees on road development that respect and uphold Indigenous knowledge and well-being is very important to ensure that road expansion takes place in accordance with applicable procedures. Land conversion, including road development, is vital to make room for economic activities (Laurance and Balmford, 2013). There is no doubt that road access will have significant effects on efforts to fight rural poverty. However, this must be accompanied by other strategic plans and limitations to environmental sustainability. There is growing concern among traditional leaders concerning the impact of road expansion on the environment. Hunting is of course one concern, but so too is the amount of plastic waste from various packaging products that pollute the river and surrounding environment (The Asia Foundation \& Indonesian Institute of Sciences - LIPI, 2018).

Roads should also have Strategic Environmental Assessment - "Kajian Lingkungan Hidup Strategis" [KLHS], and appropriate mitigation measures in place before being constructed. The implementation of KLHS is mandated by Law No. 32/2009 for Environmental Protection and 
Management. This is important to support the Papua Provincial Government in allocating 60 percent of protected forest and 90 percent of forest areas from the total area of the province into Perdasi Regional Regulation of Papua Province No. 23 (Paino, 2018). This is also in line with the Manokwari Declaration 2018, committing to conservation of 70 percent of the forest for West Papua Province (Cámara-Leret et al., 2019).

The Asia Foundation and the Indonesian Institute of Sciences (LIPI) study on roads for the community in 2018 reported that large-scale infrastructure development including the "TransPapua Highway", ports, and airports have increased the movement of goods into Papua and subsequently distributed them to rural villages. Local people have benefited from accessibility to roads to sell their agricultural products to a wider selection of markets than before. We have also found that increased connectivity via roads changes the orientation of local people using natural resources and forest products from subsistence towards market-based drivers. Thus in some parts of the Bird's Head Peninsula, selling wild meat (venison in this case), is an easy way to generate household income (Pattiselanno et al., 2019; 2020).

Increasing awareness of the importance of biodiversity at early stages of school children and youth is the most urgent step to carry out. Current nationwide media and education campaigns in the form of pamphlets, posters, public presentations and discussions have been inadequate (Lee, 2000). The Sampiri action program provides an example where community-level grassroots engagement is raising awareness of the value of wildlife conservation (Batiran and Fisher, 2020). The involvement of various stakeholders plays a critical role in increasing public awareness.

Providing people with alternative livelihoods is also important to reduce their dependence on wild meat for food and trading. An alternative program to provide domestic animals or livestock to fulfil rural household needs is urgently required. Lee (2000) suggested that in establishing nutritional programs, the most economically feasible approach is to assist in forming village cooperatives for small-scale farming of domesticated animals such as pigs, goats and chickens. Technical assistance from agricultural extension workers is also urgently needed (Gjertsen, 2011). Nasi et al (2008) suggested that farming is likely to be more profitable than hunting in communities that are adjacent to roads and that have been inhabited for a long time.

Finally, the acceleration of infrastructure development to provide more economic opportunities in rural areas should be accompanied by efforts to reduce and mitigate environmental damage. Instead of building more roads, rural communities should also be presented with genuine options to advance green infrastructure development to ensure a better future for all.

Conflicts of Interest: The authors declare no conflict of interest

\section{References}

Adefalu, L.L., Oladipo, F.O., Usman, B.A., Babalola, F.D., Amusa, T.O. \& Egere, S. (2012). Rural women perception on bushmeat trade around Kainji Lake National Park, Niger State, Nigeria. Ethiopian Journal of Environmental Studies and Management, 5(1), 20-25. http://dx.doi.org/10.4314/ejesm.v5i1.3

Alamgir, M., Campbell, M.J., Sloan, S., Goosem, M., Clements, G.R., Mahmoud, M.I., Laurance, W.F., (2017). Economic, socio-political and environmental risks of road development in the tropics. Curr. Biol. 27, R1130-R1140, https://doi.org/10.1016/j.cub.2017.08.067

Anggraeni, D. \& Watopa, Y. (2004). Kajian singkat Konservasi dan Ekonomi (RACE). Suatu usaha untuk memadukan kepentingan konservasi dan pembangunan ekonomi di Tanah Papua. Indonesia: Conservation International.

Auzel, P. \& Wilkie, D.S. (2000). Wildlife use in Northern Congo: Hunting in a commercial logging concession. In J.G. Robinson \& E.L. Bennett (Eds.), Hunting for sustainability in tropical forests. (pp. 413-426) New York: Columbia University Press. 
Batiran, K. \& Fisher, M.R. (2020). From Hunter to Protector: The Invention and Reinvention of the Nuri Talaud. Forest and Society, 4(1), 35-47. https://doi.org/10.24259/fs.v4i1.7438

Bennett, E.L., Nyaoi, A.J. \& Sompud, J. (2000). Saving Borneo's bacon: the sustainability of hunting in Sarawak and Sabah. In J.G. Robinson \& E.L. Bennett (Eds.), Hunting for sustainability in tropical forests. (pp. 305-324) New York: Columbia University Press.

Cámara-Leret, R., Schuiteman, A., Utteridge, T., Bramley, G., Deverell, R., Fisher, L.A., McLeod, J., Hannah, L., Roehrdanz, P., Laman, T.G., Scholes, E., de Fretes, Y., Heatubun, C. (2019). The Manokwari Declaration: Challenges ahead in conserving $70 \%$ of Tanah Papua's forests. Forest and Society, 3(1), 148-15. https://doi.org/10.24259/fs.v3i1.6067

Chohan, B., Imran, M. \& Cheyne, C. (2011). Roads for economic development: An analysis of urban transport policies of New Zealand and Pakistan. Proceedings of the Australasian Transport Research Forum 2011, 28-30 September 2011, Adelaide, Australia. Retrieved from http://www.atrf.info/papers/2011/2011_Chohan_Imran_Cheyne.pdf

Clayton, L.M. \& Milner-Gulland, E.J. (2000). The trade in wildlife in North Sulawesi, Indonesia. In J.G. Robinson \& E.L. Bennett (Eds.), Hunting for sustainability in tropical forests. (pp. 473-498) New York: Columbia University Press.

Clements, G.R., Lynam, A.J., Gaveau, D.L.A., Wei, L.Y., Lhota, S., Goosem, M., Laurance,S. \& Laurance, W.F. (2014). Where and How Are Roads Endangering Mammals in Southeast Asia's Forests? CMEA, 2011. Master Plan: Acceleration

Diela, T. (2015). Jokowi Vows to Finish 4,000-km Trans-Papua Highway. https://jakartaglobe.id/context/jokowi-vows-to-finish-4000-km-trans-papua-highway

Fimbel, C., Curran, B. \& Usongo, L. (2000). Enhancing the sustainability of duiker hunting through community participation and controlled access in the Lobéké region of Southern Cameroon. In J.G. Robinson \& E.L. Bennett (Eds.), Hunting for sustainability in tropical forests. (pp. 356374) New York: Columbia University Press.

Forest Watch Indonesia - FWI (2020). Infrastruktur di Papua untuk siapa? Lembar Fakta FWI, 7 Juni 2020. https://fwi.or.id/infrastruktur-di-papua-untuk-siapa/

Forman, R.T.T., Sperling, D., Bissonette, J.A., Clevenger, A.P., Chutshall, C.D., Dale, V.H., Fahrig, L., France, R., Goldman, C.R., Heanue, K., Jones, J.A., Swanson, F.J., Turrentine, T. \& Winter, T.C. (2003). Road ecology. Science and solutions. Washington: Island Press

Fusari, A. \& Carpaneto, G.M. (2006). Subsistence hunting and conservation issues in the game reserve of Gile, Mozambique. Biodiversity and Conservation 15, 2477-2495. https://doi.org/10.1007/s10531-004-8229-1

Gjertsen, H. (2011). Socioeconomic research and capacity-building to strengthen conservation of Western Pacific leatherback turtles in Bird's Head, Papua Barat, Indonesia. Jayapura: WWF Bioregion Sahul and Universitas Negeri Papua, Manokwari.

Keiluhu, H.J. (2013). The impact of hunting on Victoria Crowned Pigeon (Goura victoria: Columbidae) in the rainforests of Northern Papua, Indonesia. Dissertation of the Georg-August University School of Science (GAUSS)

Laksono, P.M., Rianti, A., Hendrijani, A., Gunawan, B., Mandacan, A., \& Mansoara, M. (2001). Igya ser hanjop masyarakat Arfak dan konsep konservasi. Kehati, PSAP-UGM, YBLBC, Yogjakarta, Indonesia

Laurance, W.F. (2014). Global 'roadmap' shows where to put roads without costing the earth. The Conversation, 28 August 2014. Retrieved from https://theconversation.com/global-roadmapshows-where-to-put-roads-without-costing-the-earth-30815

Laurance, W.F. (2009). Road to ruin. New Scientist 194, 24-25.

Laurance, W.F., Burgues, I.A. (2017). Roads to riches or ruin? Science, 358, 442. https://doi.org/10.1126/science.aao0312

Laurance, W.F. \& Balmford, A. (2013). A global map for road building. Nature, 495, 308-309. https://doi.org/10.1038/495308a 
Laurance, W.F., Sloan, S., Weng, L. \& Sayer, J. (2015). Estimating the environmental costs of Africa's massive 'development corridors'. Current Biology, 25(24), 3202-3208.. https://doi.org/10.1016/j.cub.2015.10.046

Laurance, W.F., Goosem, M. \& Laurance, S.G. (2009). Impacts of roads and linear clearings on tropical forests. Trends in ecology \& evolution, 24(12), 659-669. https://doi.org/10.1016/j.tree.2009.06.009

Lee, R.J. (2000). Impact of subsistence hunting in North Sulawesi, Indonesia and conservation options. In J.G. Robinson\& E.L. Bennett (Eds.), Hunting for sustainability in tropical forests. (pp. 455-472) New York: Columbia University Press.

Luskin M.S., Christina, E.D., Kelley, L.C., \& Potts, M.D. (2014). Modern hunting practices and wild meat trade in the oil plantation-dominated landscape of Sumatra. Human Ecology, 42, 35-45. https://doi:10.1007/c10745-013-906-8

Meijaard, E., Sheil, D., Nasi, R., Augeri, D., Rosenbaum, B., Iskandar, D., Setyawati, T., Lammertink, M., Rachmatika, I., Wong, A., Soehartono, T., Stanley, S. \& O'Brien, T. (2005). Life after logging: Reconciling wildlife conservation and production forestry in Indonesian Borneo. Center for International Forestry Research, Bogor, Indonesia. https://doi.org/10.17528/cifor/001663

Mena, P., Stallings, J.R., Regalado, J. \& Cueva, R. (2000). The sustainability of current hunting practises by the Huaorani. In J.G. Robinson \& E.L. Bennett (Eds.), Hunting for sustainability in tropical forests. (pp. 58-78) New York: Colombia University Press.

Mendelson, S., Cowlishaw, G. \& Rowcliffe, J.M. (2003). Anatomy of a bushmeat commodity chain in Takoradi, Ghana. The Journal of Peasant Studies, 31(1), 73-100. https://doi.org/10.1080/030661503100016934

Mertens, B. (2002). Spatial analysis for the rapid assessment of conservation and economy (RACE) in Papua. Task Report. France: Center for International Forestry Research (CIFOR).

Milner-Gulland, E.J., Bennett, E. \& the SCB 2002 Annual Meeting Wild Meat Group. (2003). Wild meat: the bigger picture. Trends in Ecology and Evolution, 18(7), 351-357. https://doi.org/10.1016/S0169-5347(03)00123-X

Nasi, R., Brown, D., Wilkie, D., Bennett, E., Tutin, C., van Tol, G. \& Christophersen, T. (2008). Conservation and use of wildlife-based resources: the bushmeat crisis. CBD Technical Series No. 33. Montreal, Canada: Secretariat of the Convention on Biological Diversity and Bogor, Indonesia: Center for International Forestry Research (CIFOR).

Noss, A. (2000). Cable snares and nets in the Central African Republic. In J.G. Robinson \& E.L. Bennett (Eds.), Hunting for sustainability in tropical forests. (pp. 282-304) New York: Columbia University Press.

Olupot W., McNeilage, A.J. \& Plumptre, A.J. (2009). An analysis of socioeconomics of bushmeat hunting at major hunting sites in Uganda. WCS Working Paper No. 38. New York: Wildlife Conservation Society.

Paino, C. (2018). Kajian Lingkungan Hidup Strategis untuk Selamatkan Sumber Daya Alam Papua. https://www.mongabay.co.id/2018/05/31/kajian-lingkungan-hidup-strategis-untukselamatkan-sumber-daya-alam-papua/

Pangau-Adam, M., Noske, R. and Muehlenberg, M. (2012). Wildmeat or bushmeat? Subsistence hunting and commercial harvesting in Papua (West New Guinea), Indonesia. Human Ecology, 40, 611-621. https://doi.org/10.1007/s10745-012-9492-5

Pattiselanno, F. \& Koibur, J.F. (2018). Returns from Indigenous hunting in the lowland coastal forests of West Papua, Benefits threatened wildlife species. Jurnal Manajemen Hutan Tropika, 24(1), 46-50. https://doi.org/10.7226/jtfm.24.1.46

Pattiselanno, F. \& Arobaya, A.Y.S. (2015). Trans-Papua highway: economic development versus conservation. Jakarta Post (May 21). 
Pattiselanno, F. \& Arobaya, A.Y.S. (2013). Managing tropical forests for Indonesian Papuan's livelihood. Proceeding Institute of Foresters of Australia National Conference, Canberra 7-11 April 2013. Pp. 207-215.

Pattiselanno, F., Lloyd, J.K.F., Sayer, J., Boedhihartono, A.K. \& Arobaya, A.Y.S. (2020). Wildmeat trade chain on the Bird's Head Peninsula of West Papua Province, Indonesia. Journal of Ethnobiology, 40(2), 202-2017. https://doi.org/10.2993/0278-0771-40.2.202

Pattiselanno, F., Apituley, J.R.M., Arobaya, A.Y.S. \& Koibur, J.F. (2019). Using wildlife for local livelihood - Experiences from the Bird's Head Peninsula, West Papua Indonesia. Biodiversitas, 20(7), 1839-1845. https://doi.org/10.13057/biodiv/d200708

Pattiselanno, F. (2006). The wildlife hunting in Papua. Biota, 11(1), 59-61. https://doi.org/10.24002/biota.v11i1.2824

Pattiselanno, F. (2004). Wildlife utilization and food security in West Papua, Indonesia. Southeast Asian Regional Center for Graduate Study and Research in Agriculture (SEARCA) Agriculture and Development Seminar Series. Los Baños: SEARCA

Pratt, C. and Lottermoser, B.G. (2007). Trace metal uptake by the grass Melinis repens from roadside soils and sediments, tropical Australia, Environmental Geology,52(8), 1651-1662. https://doi.org/10.1007/s00254-006-0610-9

Richard, S.J. \& Suryadi, S. (Eds). (2002). A biodiversity assessment of Yongsu- Cyclops Mountain and the southern Mamberamo Basin, Papua, Indonesia. Rapid Assessment Program (RAP). Bulletin of Biological Assessment No. 25. Washington DC. Conservation International

Robinson, J.G. \& Bennett, E.L. (2004). Having your wildlife and eating it too: an analysis of hunting sustainability across tropical ecosystems. Animal Conservation, 7, 397-408. https://doi.org/10.1017/S1367943004001532

Robinson, J.G. \& Bennett, E.L. (Eds.) (2000). Hunting for sustainability in tropical forests. New York: Columbia University Press.

Robinson, J.G., Redford, K.H. \& Bennett, E.L. (1999). Wildlife harvest in logged tropical forests. Science, 284, 595-596. https://doi.org/10.1126/science.284.5414.595

Shepherd, C.R. \& Magnus, N. (2004). Nowhere to hide: The trade in Sumatran Tiger. TRAFFIC Southeast Asia

The Asia Foundation \& Indonesian Institute of Sciences - LIPI (2018). Jalan untuk komunitas: Membangun infrstruktur konektivitas jalan untuk penghidupan Orang Asli Papua dan Lingkungan Hidup (Ringkasan Eksekutif). https://asiafoundation.org/wpcontent/uploads/2018/10/Ringkasan-Eksekutif-Rapid-Assessment-Infra-Papua.pdf

Trombulak, S.C. \& Frissel, C.A. (2000). Review of ecological effects of roads on terrestrial and aquatic communities. Conservation Biology, 14, 18-30. https://doi.org/10.1046/j.15231739.2000.99084.x

Walhi (2020). Menuntut Keterbukaan PUPR Atas Proyek Jalan Trans Papua. (https://www.walhi.or.id/menuntut-keterbukaan-pupr-atas-proyek-jalan-trans-papua). 